\title{
The Role of Information Technology in Customers' Service Delivery and Firm Performance: Evidence from Nigeria's Insurance Industry
}

\author{
Adekunle Abiodun Idris ${ }^{1}$, Tajudeen Abayomi Olumoko ${ }^{1} \&$ Sunday Stephen Ajemunigbohun ${ }^{2}$ \\ ${ }^{1}$ Department of Business Administration and Management Technology (Marketing Unit), Lagos State University, \\ Lagos, Nigeria \\ ${ }^{2}$ Department of Accounting and Finance (Insurance Unit), Lagos State University, Lagos, Nigeria \\ Correspondence: Sunday Stephen Ajemunigbohun, Department of Accounting and Finance (Insurance Unit), \\ Lagos State University, P.M.B. 0001, LASU Post Office, Ojo, Lagos, Nigeria. Tel: 234-705-534-2854. E-mail: \\ insurancelecturerlasu2009@yahoo.com
}

Received: October 2, $2012 \quad$ Accepted: April 1, 2013 Online Published: May 28, 2013

doi:10.5539/ijms.v5n4p59 URL: http://dx.doi.org/10.5539/ijms.v5n4p59

\begin{abstract}
Information technology is crucial for a communication based process. Therefore, this study presents an investigation of the significant role of information technology in customer service delivery and firm performance in selected insurance companies in Nigeria. Specifically, three hypotheses were tested. They are to determine whether: (i) customers are not aware of the availability of IT facilities in their dealings with the Nigerian insurance companies; (ii) the use of IT does not enhance the performance efficiency of insurance organizations in Nigeria; and (iii) providing quality customer service delivery will not enhance organizational performance of insurance companies. The survey research design for the study was a cross examination. The study sample consisted of 112 participants made up of IT managers, marketing managers, and underwriting managers drawn from 25 insurance companies which were randomly selected from the directory of member companies. One-sample T-test and simple frequency percentage tables were used for data analysis. The study revealed that most customers hardly use online services in their engagement with the Nigerian insurance companies even with the level of awareness created which depicts a low level business relationship. Thus, many of the insurance organizations indicated that they experienced high performance efficiency in their investment in and adoption of information technology. This study recommends that insurance administrators and regulators at all levels should gather relevant information as regards factors that may assist in contributing meaningfully to the usefulness of IT in effective service delivery. They should also undertake optimal investment in IT, provide quality service delivery to customers and regularly evaluate IT usage in every department of insurance organizations in Nigeria in order to take appropriate strategic decisions capable of enhancing firm performance.
\end{abstract}

Keywords: information technology, customer service delivery, performance, insurance companies, Nigeria

\section{Introduction}

It has been widely acknowledged that any sectorial growth and management need be effective; especially the service industry such as: banking, insurance, entertainment, tourism, engineering and the likes, and oriented customer service need be consciously achieved. Thus, the ability to extend customer knowledge and develop successful relationship with customers hinge on the ability of an organization to know it's potential markets, singular needs, expectation and dynamic desires.

However, technology is employed to capture information on customers, which in turn is used to monitor the customer's buying behavior and to relate with them through personalized offers (Egan, 2004). Oghojafor, Aduloju and Olowokudejo (2011) had noted that, in the world of business, electronic commerce is the basis for which strategic-oriented business create relationship within their environment and more so strategized for new competitive edge. To corroborate this position, Murphy (2000) had earlier postulated that customer friendliness, acceptance and satisfaction propagate organization's sustainability. A review of previous studies has shown that very little has been done in the Nigerian insurance industry concerning the integration of information technology (IT), customer service and firm performance measures. According to a submission of Achimugu et al. (2009), not too many organizations in Nigeria had bought into IT philosophy. Sawyer, Ebrahimi, and Luk (2003) reveal in their study done in Hong Kong and Nigeria respectively that there exist coexistence between perceived strategic 
uncertainty, scanning of environment, use of information source, and organizational performance.

Data warehousing integrates information about customers and other stakeholders in an organization's network of relationships. With this knowledge, the organization can better customize and target communication efforts on goods and services to boost the organization's competitive power and increase customer retention. The data warehouse is an organizational key knowledge instrument and can be used to stimulate indices of intimacy and connectedness (Gummesson, 2008).

Technology is to the advantage of the customer and should lead to customer loyalty, as organizations can communicate with customers using up-to-date techniques on a real time basis which will remove uncertainty and will lead to the creation of trust. The created trust will lead to an enduring desire from the customers to maintain valued relationships with the organization, as trust remains a potential component of insurance brands (Ndubisi \& Wah, 2005; Brenda, 2002). The bonding relationships between customers and organizations are hinged on trust which is aimed at achieving an overall positive outcomes, and thus higher levels of trust and commitment in turn are attached with higher customer retention level, and this brings about increased organizational performance (Botha \& Van Rensburg, 2010; Read, 2009).

\section{Objectives of the Study}

This study is concerned with examining the role information technology plays in customer service delivery and firm performance in selected insurance organizations in Nigeria; and thus to examine the relationship that subsists between information technology, customers service delivery and firm performance.

\section{Research Questions}

For the purpose of this study, the following relevant research questions were set:

i. Are customers aware of the use of IT facilities in their dealings [i.e. request for insurance coverage, filling of proposal forms and claim form, complaint lodgment, e.t.c] with the Nigerian insurance companies?

ii. Does the use of IT positively affect the performance efficiency of insurance organizations in Nigeria?

iii. Will the incorporation of quality customer service delivery in the Nigerian insurance market enhance performance level?

\section{Research Hypotheses}

To provide answer to the questions stated above, the following testable hypothetical statements were considered:

i. Ho: Customers are not aware of the availability of IT facilities in their dealings with the Nigerian insurance companies;

ii. Ho: The use of IT does not enhance the performance efficiency of insurance organizations in Nigeria; and

iii. Ho: Providing quality customers service delivery will not enhance the organizational performance of an insurance company.

\section{Review of Literatures}

\subsection{Information Technology in Customer Service Delivery}

Delivering the required service to the customer is challenging. Either interacting personally or through information processes, customers' perception concerning a market offering is built upon the ability of the service provider to attractively convince their various target market. Rust and Chung (2006) state that customer-information gathering has a greater potential link with meeting customers' needs better. More so, satisfying customers' needs are based on customers' purpose and customer-oriented services channeled to their various needs in order to solve particular problems of the customers.

Furey (1991) points at customer service delivery enhancement via convenience provision, information provision for management use and extra services offerings as factors for information technology practices. Thus, many competing roles of IT in service embraces entry limitation, enhancing production, and generating revenue (Fitzsimmons \& Fitzsimmons, 1997). Heskett et al. (1997) added that the emergence of the application of information technology is a crucial feature to customer satisfaction via various channels of delivery. Customer data is considered to have value and the potential to augment the customer-organization relationship.

The storing of data for later retrieval is known as data warehousing, and the manipulation of the warehoused data is known as data mining. These new technologies can make customers data available up-to-the-second and allow organizations to communicate with customer directly. These new technologies embrace the internet, computer-telephony and telecommunication in call centers (Evan, O’Malley \& Patterson, 2004). A tactical 
improvement in an organization's bargaining position relative to those of customers is aimed at providing unique and meaningful information and services that require drastic changes.

Information technology can promote meaningful information or service offerings previously unavailable and potentially of very customers high value (Bakos \& Treacy, 1986). Thus, when customer relationship is technology inclusive, it supports directly and/or by coordinating and restoring confidence in customer especially when changes are experienced in both training and other organizational changes (Evangelia \& Michalis, 2006; Sweat \& Hibbard, 1999). Thus, enhancing customer services can be endangered if mismanagement of technology exists; even in its delivery (Asbrand, 1997).

\subsection{Information Technology and Firm Performance}

Several authors have identified the underutilization of information technology as a serious problem facing both information systems and business managers (Benjamin et al., 1984; Parsons, 1983a; Bullen \& Rockart, 1981). Suggestions have been made that better measures of the efficiency and effectiveness of organizational functions via information technology reflect major changes in organization's current structure. For examples, Gerstein and Reisman (1982) identified a need for the development of measures of the impact of information systems on specific functions. Keen (1981) suggested earlier that important changes in the fundamental nature of work and the structure of organizations are needed, so that better use of information technology can be made. He predicted that information technology will become the backbone of corporations, and that organizations will develop around their telecommunication systems.

Efficient and effective improvement of organizations is central to the functionality of information systems. Rockart and Scott- Morton (1984) posit that traditional information systems are crucial for firm's competitive position. They use a format of Leavitt's (1965) organizational representation to show that these systems through their effect on staff, structure of the organization, and process of management can affect competitive result. The studies of Parsons (1983b), and Ives and Learmonth (1984) suggest that information technology have created opportunities for firms to compete. They suggested four aspects of opportunities for IT competing and supportive oriented strategy and performance of a firm, viz: operational and functional efficiency improvement; usage of inter-organizational relatedness; IT product initiative; and acquiring bargaining benefit overriding one's customers and suppliers influence.

Burns and Vaivio (2001) were of the opinion that information technology advancement will help driven innovation and thus assist in collecting, measuring, analyzing and communicating information in and around the organizations. The strategic facet of information technology is a significant perspective in the views of authors, comprising Porter and Millar (1985), who posited that a firm competitive advantage is the key. Das, Zahra and Warkentin (1991) came up with four dimensional approaches to deploying information technology, that is, distinctive skills, the essence of IT, information system design and evolution, and technological, organizational, and administrative infrastructures. Bergeron and Raymond (1995) also model five elements, viz: information system positioning, the strategic use of information system, contemporary technologies, the architectural planning, and security.

As noted in the study of Henderson and Venkatraman (1993), and Durand and Bouzidi (2008), it is extremely significant to annex IT with business strategy and more so, organizations have to utilize IT strategy in line with their strategic business objectives. They thus pinpoint that strategic association of information systems permit organization's performance intents explicated in business strategy. Previous studies have shown, among all others, that firm with high competitive strategies have unique information systems than those with aggressiveness in their strategies. Chan et al. (1997) found that combining more strategic business intent with highly competitive information systems will impart positively on the performance a firm. Li and Ye (1999) proposed in their study of the dynamism of the environment, strategy of the firm and collaboration between the firms' investment in information technology and their results. Their study and that of Hyvonen (2007) came up with the understanding that achieving dynamic environment in line with expanding market for product through strategic-oriented involvement requires greater investment in IT.

\subsection{Customers Service Delivery, Information Technology and Performance Measures in Insurance Industry}

Information technology is crucial for a communication-based process. Therefore, communication ability of an organization when relating to its interested customers hinged on information that are timely and trustworthy (Ndubisi, 2007). More so, the functional ability of an organization is a two-way thing, hence information management system involves management, employees and customers. In insurance, firms have commenced a wide array of on-line services, including online sales, needs analysis (Adelman \& Dorfman, 2002) and customer services (for example, online policyholder account information, claims management and processing, and group insurance certificate). These are in addition to other germane and vital situations such as globalization and 
regulatory reforms that insurance firms must contend with. These developments had brought in more competitiveness in the world of insurance (Graven, 2002).

According to Fagbemi (2006), customer-centered services incorporate customers' concerns at each stage of the service design and delivery process. Rust and Chung (2006) affirm that productivity, profitability, and improved organizational performance are usually the end-result whenever an organization is concerned with customer service-oriented programmes. According to Gan et al. (2006) and Varki and Colgate (2005), a customer focused service is a significant variable which has helped promote cordial relationship between firms and their numerous customers. The Microsoft Dynamics Report (2009) suggests that to provide services of superior quality to customer, insurers need to take a comprehensive dimensional perspective of those customers that give an insight into how to complement their services and sales requirements. Therefore, with adequate and relevant business information and management process, insurers would find it easy to streamline their operations, have customer in mind, and optimize customer processes, which results in increase of revenue and improve their competitive level in the world market.

Over a decade ago, it was emphasized that benefits of information technology to the insurance industry in Nigeria would include faster and accurate ways of getting things done, relieving workers of the burden of performing minor repetitive tasks and elimination of unnecessary use of resources such as paper work (Data Board Limited, 1998). Matassa et al. (2003) suggested investment in IT as a representation of almost all investment in technical capital which affects productivity the more. According to Arora (2003), the insurance industry has been lagging behind the other financial services to embrace this new change within its activities. However, incorporating technology in our marketing offerings encourages a competitive standard (Karimi, Somers \& Gupta, 2001). More and more service firms such as insurance organizations and banks are providing IT based service options to their customers. Jeffers (2003) posits that the strength and competitive advantage of an organization is complementarities between IT contribution, firm performance and leveraging service delivery of customers.

A major firm's objective is the improvement of its performance. This serves the strategic goal of business and information system (Delone \& McLean, 1992). Croteau and Bergeron (2001) imply that performance measurement in any organization has no standardized link. They were of the opinion that two possible approaches are used in measuring performance. These are the objective or quantitative approach which comprises data of financial elements (such as income and productivity indicators) and the subjective or qualitative approach which indicates respondents' perception. Berger et al. (2000) provided distinctive representation of some providers of financial service who see conglomeration as a more economically efficient business strategy and others who see their core competent areas as critical.

Investment in quality information system had paved way for insurers to devote efforts to customer service delivery. A more pricing and transparent service delivery exists in an environment competitive for customer reliance (D'Arcy \& Doherty, 1990). Graven (2002) notes that a more glaring pricing attracts customers and encourages insurer firms bid for business having alternated the price. While Lohman et al. (2004) provide evidence which gave an indication of the alignment between improved performance measurement and supply chain management, Folan and Browne (2005) segmented the development of measures of performance into four different categories, viz: (i) frameworks; (ii) systems; (iii) inter-organizational performance measurement and (iv) recommendations.

In providing a profitability representation of an insurance company, insurance performance measures were developed by Calandro (2001). He further points out three major drivers in insurance performance measurement that is, investment, production and re- insurance. The use of insurance performance measurement serves as an evaluation instrument and diagnostic control mechanism, and thus, an avenue through which an insurer can more deeply fathom the trade-offs incorporated in its business decisions and improve its oversight of each area of operations which could lead to new initiatives, strategies and management practices. Paramasivan (2008) notes that IT today is an indispensible component of insurance business and is linked to all spheres of core operations such as Marketing, Underwriting, Claims management and Rate making. The usage of IT can be attributed to increasing emphasis on quality consciousness, optimum utilization of resources, integration of various administration processes, cost cutting, right sizing, international standardization, providing web based training to intermediaries, consumer education, detection of fraud, closer monitoring of implementation of company policies, shorter product development /launching time, etc. Information Technology is, therefore, pertinent and being used in the following applications in the insurance industry: clients' administration, product control, underwriting, claims management, reinsurance cover, accounts, management information \& control system, document fulfillment and reporting. 


\section{Methodology}

\subsection{Research Design, Instrumentation, Administration and Tests of Validity}

A survey research design was employed for the study. Data were collected among the Nigerian insurance companies. The major data gathering instrument employed in this study was the questionnaire. The questionnaire followed the formulation of the above research questions and hypotheses. It consisted of two parts, A and B. Part A consisted of participant's personal data, while part B contained general statement related to the research variables. Respondents were requested to state their perception of the issues under investigation by completing the questionnaire which was drawn using a five - point Likert-type scaling measurement of 'Strongly agree', Agree', 'Undecided', 'Disagree', and 'Strongly Disagree'.

Among member companies of the Nigerian Insurers Association, 25 companies were selected randomly from the directory as documented in the Nigeria Insurance Digest (2011, p.35). The choice of the selected companies was according to their rank in order of gross premium and market share (that is, top 25 member companies of the Nigerian Insurers Association). The sample population for this study was drawn from Lagos, the commercial center of Nigeria, which houses the largest number of insurance companies in Nigeria. A pre-structured questionnaire was administered to 150 respondent employees using the stratified sampling technique to obtain information from three strata of employees (that is, IT managers, Marketing managers and Underwriting managers). Two respondents were drawn from each of the three categories of employees from each of the 25 insurance companies; that is, 6 per company $\times 25$ companies $=150$ respondents. To ensure a high response rate from the respondents, the researchers made series of telephone calls and visits to the selected companies. 129 copies of the questionnaire were retrieved out of which 112 correctly completed copies were used, that is, a $75 \%$ effective response rate.

The research instruments were validated using construct validity and content validity. Nevertheless, an external validity was also sought for. Construct validity was sought for in this study through an extensive use of well-grounded theory and literature from other studies. This provides theoretical relationship and cumulativeness with previous work. The content validity is developed by giving a set of draft questionnaire to few selected IT managers, marketing managers, underwriting managers in insurance companies and academicians in the field in insurance. These experts reviewed the content and gave suggestions that assisted the researchers to present the items within the linguistic understanding of the respondents. To ensure the soundness of external validity of this study, we conducted a check using the approach introduced by McGrath, MacMillan and Venkatraman (1995) as cited in Oyedijo (2012).This embraced active and relentless discussion of the results with knowledgeable and experienced colleagues who are at the next lower rank of the final respondents and not a part of the sample but are within the same companies. Their high extent of agreements with the result provided evidence of the external validity of the results. The detail of the research methods is summarized in the appendix.

\section{Results and Findings}

\subsection{Data Presentation and Analysis}

In presenting and analyzing the collected data, simple frequency and percentage tables have been used, while hypotheses formulated were tested using one sample T-test statistical instrument with the support of the SPSS version 17.0.

\subsection{Analysis of Responses to Research Questions}

7.2.1 Customers' Awareness of the Availability of IT Facilities in Their Dealings with the Nigerian Insurance Companies

Table 1. Simple frequency percentage table showing responses to research question 1

\begin{tabular}{|c|c|c|c|}
\hline Alternatives & Responses & $\begin{array}{l}\text { Percentage } \\
(\%)\end{array}$ & Aggregate $(\%)$ \\
\hline Strongly agree & 31 & 27.68 & \\
\hline Agree & 49 & 43.75 & 71.43 \\
\hline Undecided & 27 & 24.10 & 24.10 \\
\hline Disagree & 05 & 04.47 & \\
\hline Strongly disagree & 00 & 00.00 & 04.47 \\
\hline Total & 112 & 100 & 100 \\
\hline
\end{tabular}

Source: Survey Report, 2012. 
As presented in the above table, $71 \%$ agreed to the question, $24 \%$ were undecided while $5 \%$ indicated their disagreement. This indicates that insurance companies provide their customers with information via IT network.

7.2.2 The Use of Information Technology Has Positively Affected the Performance Efficiency of My Organization

Table 2. Simple frequency percentage table showing responses to research question 2

\begin{tabular}{llll}
\hline Alternatives & Responses & $\begin{array}{l}\text { Percentage } \\
(\%)\end{array}$ & Aggregate (\%) \\
\hline Strongly agree & 31 & 27.68 & \\
Agree & 59 & 52.68 & 80.36 \\
Undecided & 14 & 12.50 & 12.50 \\
Disagree & 08 & 07.14 & \\
Strongly disagree & 00 & 00.00 & 7.14 \\
Total & 112 & 100 & 100 \\
\hline
\end{tabular}

Source: Survey Report, 2012.

On aggregate, $80 \%$ of the respondents agreed that IT has continually improved the performance level of their organizations. This, in the study of Harris and Katz (1988) on forty insurance organizations, presents evidence that many successful companies spent on information technology a higher percentage of their investments than other less successful counterparts. While 13\% were undecided, $7 \%$ expressed their disagreement.

7.2.3 Quality Service Delivery Has Enhanced Performance Level in My Organization

Table 3. Simple frequency percentage table showing responses to research question 3

\begin{tabular}{llll}
\hline Alternatives & Responses & $\begin{array}{l}\text { Percentage } \\
(\%)\end{array}$ & Aggregate (\%) \\
\hline Strongly agree & 52 & 46.43 & \\
Agree & 34 & 30.36 & 76.79 \\
Undecided & 23 & 20.53 & 20.53 \\
Disagree & 03 & 2.68 & \\
Strongly disagree & 00 & 00.00 & 2.68 \\
Total & 112 & 100 & 100 \\
\hline
\end{tabular}

Source: Survey Report, 2012.

Responses to table 3 above proved that $77 \%$ were in support that providing customers with quality service delivery, in terms of prompt claims payment and flexible policy plans, will increase the performance of Nigerian insurance companies. Also, 20\% and 3\% indicated their indifference and disagreement. As expected, this shows that effective quality service delivery in insurance organizations results in increased performance.

\subsection{Test of Hypotheses}

The hypothesis test seek to further analyze questions for the research which relates to the role information technology plays in customers service delivery and organizational performance of selected companies in the Nigerian insurance industry. Three hypotheses were formulated for clearer direction and understanding of the study and these were tested using a one sample T-test with the support of Statistical Package for Social Science (SPSS) version 17.0.

7.3.1 Hypothesis 1: Customers Are Not Aware of the Availability of IT Facilities in Their Dealings with the Nigerian Insurance Companies

Table 4. Simple frequency percentage table showing responses to Hypothesis 1 (Statement 4)

\begin{tabular}{lllllll}
\hline Hypothesis & $\begin{array}{l}\text { Strongly } \\
\text { Agree }\end{array}$ & Agree & Undecided & Disagree & $\begin{array}{l}\text { Strongly } \\
\text { Disagree }\end{array}$ & Total \\
\hline Responses & $41(36.6 \%)$ & $38(33.9 \%)$ & $22(19.6 \%)$ & $09(8.1 \%)$ & $02(1.8 \%)$ & $112(100 \%)$ \\
\hline
\end{tabular}

Source: Survey Report, 2012. 
Table 5. Analysis of hypothesis 1

\begin{tabular}{lllllll}
\hline & Test Value $=0$ & & & \\
\cline { 2 - 6 } & $\mathrm{t}$ & $\mathrm{df}$ & Sig. (2-tailed) & \multicolumn{2}{l}{$\begin{array}{l}\text { Mean } \\
\text { Difference }\end{array}$} & \multicolumn{2}{c}{ Interval of the Difference } \\
\cline { 3 - 7 } & & & & Lower & Upper \\
\hline $\begin{array}{l}\text { Customer } \\
\text { awareness }\end{array}$ & 40.811 & 111 & .000 & 3.95536 & 3.7633 & 4.1474 \\
\hline
\end{tabular}

The above result shows that the calculated value of 40.81 is greater than the p-value of 0.000 at $5 \%$ significant level (i.e. $\mathrm{D}_{\text {cal }}=40.81>\mathrm{p}=0.000$ ). Therefore, in compliance with the decision rule, the null hypothesis (Ho), stating that customers are not aware of the availability of IT facilities in their dealings with the Nigerian insurance companies is rejected (see Table 4 for respondents' responses). This indicates that customers are aware of the availability of IT facilities in their dealings with the Nigerian insurance companies. Once more, this underlines the fact that Nigerian insurance companies have been IT compliant and thus have been relating to their various customers via IT networks.

7.3.2 Hypothesis 2: The Use of IT Does Not Enhance the Performance Efficiency of Insurance Organizations in Nigeria

Table 6. Simple frequency percentage table showing responses to Hypothesis 2 (Statement 9)

\begin{tabular}{lllllll}
\hline Hypothesis & $\begin{array}{l}\text { Strongly } \\
\text { Agree }\end{array}$ & Agree & Undecided & Disagree & $\begin{array}{l}\text { Strongly } \\
\text { Disagree }\end{array}$ & Total \\
\hline Responses & $07(6.3 \%)$ & $13(11.6 \%)$ & $19(16.9 \%)$ & $24(21.4 \%)$ & $49(43.8 \%)$ & $112(100 \%)$ \\
\hline
\end{tabular}

Source: Survey Report, 2012.

Table 7. Analysis of hypothesis 2

\begin{tabular}{lllllll}
\hline & Test Value=0 & & & & \\
\cline { 2 - 6 } & $\mathrm{t}$ & $\mathrm{df}$ & Sig. (2-tailed) & $\begin{array}{l}\text { Mean } \\
\text { Difference }\end{array}$ & \multicolumn{2}{c}{ Interval of the Difference } \\
\cline { 3 - 6 } & & & & 2.15179 & 1.9131 & 2.3905 \\
\hline $\begin{array}{l}\text { IT \& insurance } \\
\text { performance } \\
\text { efficiency }\end{array}$ & 17.862 & 11 & .000 & & & \\
\hline
\end{tabular}

The result above shows that the calculated value of 17.86 is greater than the p-value of 0.000 at $5 \%$ level of significance (i.e. $\mathrm{D}_{\text {cal }}=17.86>\mathrm{p}=0.000$ ). Therefore, in compliance with the decision rule, the null hypothesis (Ho) that, according to the respondents, the use of information technology does not enhance performance efficiency of insurance organizations in Nigeria is rejected (see Table 6 for respondents' responses). It is, therefore, logical to conclude that information technology is supportive to the performance efficiency of insurance companies in Nigeria. Again, this result supports the view of Jeffers (2003) who posited that the strength and competitive advantage of an organization is complementarities between IT contribution, firm performance and leveraging service delivery of customers.

7.3.3 Hypothesis 3: Providing Quality Customers Service Delivery Will Not Enhance the Organizational Performance of Insurance Company

Table 8. Simple frequency percentage table showing responses to Hypothesis 3 (Statement 20)

\begin{tabular}{lllllll}
\hline Hypothesis & $\begin{array}{l}\text { Strongly } \\
\text { Agree }\end{array}$ & Agree & Undecided & Disagree & $\begin{array}{l}\text { Strongly } \\
\text { Disagree }\end{array}$ & Total \\
\hline Responses & $02(1.8 \%)$ & $04(3.6 \%)$ & $23(20.5 \%)$ & $49(43.8 \%)$ & $34(30.3 \%)$ & $112(100 \%)$ \\
\hline
\end{tabular}

Source: Survey Report, 2012. 
Table 9. Analysis of hypothesis 3

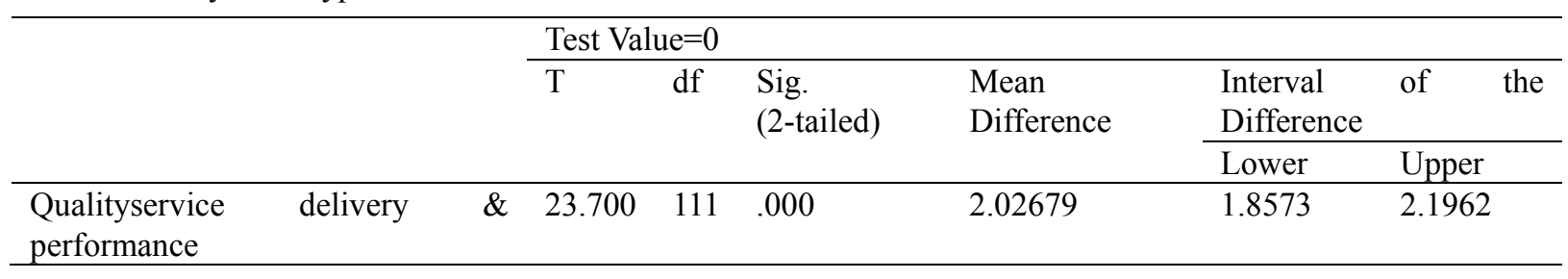

From the result above, the calculated value of 23.70 is greater than the p-value of 0.000 at $5 \%$ level of significance (.i.e. $\mathrm{D}_{\text {cal }}=23.70>\mathrm{p}=0.000$ ). Therefore, in compliance with the decision rule, the null hypothesis (Ho) that providing quality service delivery will not enhance the performance of an insurance company is rejected (see Table 8 for respondent's views). The researchers then conclude that providing quality customer service delivery enhances the performance of an insurance organization. This, therefore, confirms the earlier studies of Berry (1983), Gronroos (1990), and Morgan and Hunt (1994), who noted that quality customer service delivery tends to increase returns, profits, and value of shareholder through marketing activities directed towards improving, maintaining and increasing successful relationships between companies and their customers. Madueme (2009) concurs that investment in IT positively affects efficiency and thus, strengthens quality service delivery.

\section{Conclusion, Recommendations and Future Research}

This study attempts to find out how relevant and effective information technology is perceived in quality service delivery to customer and also, to examine its effect on insurance companies' performance in Nigeria. However, the study found that in most companies, customers find it difficult to perform vital transactions on-line without necessarily being present physically at the companies (responses to statement 3 on the questionnaire). This is because many customers have not bought into the idea of the use of IT as means of reaching their respective insurance companies. Furthermore, responses from the various companies show further that many insurance companies have started relating with their customers via IT networks, and have also encouraged customers by reaching out to them through electronic mails, text messages and the likes. The study also found that a good number of the insurance companies are of the opinion that IT has aided their performance levels. This study is consistent with others [such as Hyvonen (2007), Chan et al. (1997), Harris \& Katz (1988), among others]; it presents evidence that advances in information systems may have positive impact on the performance of any business. Findings from this study also gave supporting evidence that greater investments in information technology are perceived as enhancing organizations' profitability level.

Conclusively, this study reveals that Nigerian companies are on the proper path to adopt and effectively use information technology to improve customers' service delivery and this will in turn affect firm performance positively. As suggested by these findings, insurance companies in Nigeria can better their customers service delivery process by investing more in information technology, providing IT training facilities to staff from time-to-time and educating their customers on the need for on-line transactions to ensure smooth, faster and quality service. All these would lead to increased profits.

Having considered the findings, this study recommends therefore that:

i. Insurance administrators and regulators at all levels should gather relevant information as regards factors that may assist in contributing meaningfully to the usefulness of information technology in effective service delivery;

ii. Insurance companies in Nigeria are encouraged to improve on their investment level in their IT so as to further enhance performance efficiency in every aspect of their business operations;

iii. Insurance organizations should ensure they provide IT enhanced quality service delivery that are customer friendly to the insuring population;

iv. Insurance regulators at all levels should endeavour to evaluate the extent to which information technology has been put to effective use in every department of the industry;

v. Insurance companies, administrators and regulators should pool their resources together in order to organize seminars, workshops and symposia to enlighten both prospective and existing insurance customers on the need to embrace the use of IT in their various dealings; and 
vi. Regulators should develop a regulatory framework that has the capability to regularly monitor and tackle the incidences of poor quality services, rate cutting, premium defaulting of compulsory insurance, and the likes with the aid of IT usage.

This research suggests further that future studies should look into cost implication of the use of IT in the service delivery efficiency of insurance companies in the developing world. More so, efforts need be put together to ascertain and evaluate quality of insurance services in terms of responses to insurance claims payment and settlement, availability of insurance policy, cost of insurance, regular supply of information, flexibility in policy plans (that is, duration of policy, premium adjustment, e.t.c.), availability of Insurance Brokers/Agents and courtesy of contact staff. Lastly, future research can endeavour to investigate reasons why the insuring publics do not often utilize the available IT facilities in their dealings with their respective insurance companies.

\section{References}

Achimugu, P., Oluwagbemi, O., Oluwaranti, A., \& Afolabi, B. (2009). Adoption of information and communication technologies in developing countries: An impact analysis. Journal of Information Technology and Impact, 9(1), 37-46.

Adelman, S. W., \& Dorfman, M. S. (2002). An analysis of the quality of internet life insurance advice. Risk Management and Insurance Review, 5(2), 135-154. http://dx.doi.org/10.1111/1098-1616.00012

Arora, A. (2003). E-insurance analysis of the impact and implications of e-commerce on the insurance industry (unpublished master's thesis). Cass Business School, Faculty of Actuarial Science and Statistics, University of Florida.

Asbrand, D. (1997). Is your automated customer service killing you? Retrieved from http://www. datamation.earthweb.com

Bakos, J. Y., \& Treacy, M. E. (1986). Information technology and corporate strategy: A research perspective. MIS Quarterly, June, 107-119. http://dx.doi.org/10.2307/249029

Benjamin, R. L., Rockert, J. F., Scott-Morton, M. S., \& Wyman, J. (1984). Information technology: A strategic opportunity. Sloan Management Review, 25(3), 3-14.

Berger, A. N., Cummons, J. D., Weiss, M. A., \& Zi, H. (2000). Conglomeration versus strategic focus: Evidence from the insurance industry. Journal of Financial Intermediation, 9(4), 323-362. http://dx.doi.org/10.1006/jfin.2000.0295

Bergeron, F., \& Raymond, L. (1995). The contribution of IT to the botton line: A contingency perspective of strategic dimensions. Proceedings of the $16^{\text {th }}$ International Conference on Information System, December $13^{\text {th }}-15^{\text {th }}$, Amsterdam, $167-181$.

Berry, L. L. (1983). Relationship marketing. In L. Berry, L. G. Shostack, \& G. L. Upah (Eds.), Emerging perspectives on service marketing (pp. 28-30). Chicago: American Marketing Association.

Botha, G., \& Van Rensbury, A. C. (2010). Proposed business process improvement model with integrated customer experience management. South African Journal of Industrial Engineering, 2(1), 45-57.

Brenda, S. (2002). The insurance company branding challenge. Insurance Marketing Magazine. Florida: Agent Media Corporation, February/ March.

Bullein, C. V., \& Rockart, J. F. (1981). A primer on critical success factor. CISR Working Paper 69, Center for Information System Research, Massachusetts Institute of Technology, Cambridge, June.

Burns, J., \& Vaivio, J. (2001). Management accounting change. Management Accounting Research, 12, 389-402. http://dx.doi.org/10.1006/mare.2001.0178

Calandro Jr, J. (2001). The insurance performance measure (IPM): Bringing value to the insurance industry. Journal of Applied Corporate Finance, 14(4), 8-13.

Chan, Y., Huff, S., Barclay, D., \& Copeland, D. (1997). Business strategic orientation, information systems strategic orientation, and strategic alignment. Information System Research, 8, 125-150. http://dx.doi.org/10.1287/isre.8.2.125

Croteau, A. M., \& Bergeron, F. (2001). An information technology trilogy: Business strategy, technological deployment and organization performance. Journal of Strategic Information System, 20(2), 77-99. http://dx.doi.org/10.1016/S0963-8687 (01)00044-0

D’Arcy, S. P., \& Doherty, N. A. (1990). Adverse selection, private information, and low-balling in insurance 
markets. Journal of Business, 63(2), 145-164. http://dx.doi.org/10.1086/296500

Das, S. R., Zahra, S. A., \& Warkentin, M. E. (1991). Integrating the content and process of strategic MIS planning with competitive strategy. Decision Sciences, 22, 953-984. http://dx.doi.org/10.1111/j.1540-5915.1991.tb01902.x

Data Board Limited. (1998). Information technology and the insurance industry in Nigeria. The Nigerian Insurer, 9-21.

Delone, W. H., \& McLean, E. R. (1992). Information systems success: The quest for the dependent variable. Information Systems Research, 3(1), 60-95. http://dx.doi.org/10.1287/isre.3.1.60

Durand, A., \& Bouzidi, L. (2008). The alignment between customer relationship management and IT strategy: A proposed research model. Proceedings of the Southern Association for Information System Conference, March 13-15, USA, 1-6.

Egan, J. (2004). Relationship marketing: Exploiting relational strategies in marketing (2nd ed.). Essex: Pearson Education Limited.

Evangelia, B., \& Michalis, M. (2006). Customer relationship management: A case study of a Greek Bank. Journal of Financial Services Marketing, 11(2), 116-124. http://dx.doi.org/10.1057/palgrave.fsm.4760014

Evans, M., O’Malley, L., \& Patterson, M. (2004). Exploring direct and customer relationship marketing (2nd ed.). London: Thomson.

Fagbemi, A. O. (2006). Customer service delivery in public sector management. Lagos: Concept Publication Limited.

Fitzsimmons, J. A., \& Fitzsimmons, M. J. (1997). Service management: Operations, strategy, and information technology (2nd ed.). New York: Irwin/McGraw-Hill.

Folan, P., \& Browne, J. (2005). A review of performance measurement: Towards performance management. Computers in Industry, 56, 663-680. http://dx.doi.org/10.1016/j.compind.2005.03.001

Furey, T. R. (1991). How information power can improve service quality. Planning Review, 19(3), 24-26. http://dx.doi.org/10.1108/eb054325

Gan, C., Cohen, D., Clemes, M., \& Chong, E. (2006). A survey of customer retention in the New Zealand banking industry: Banks and bank systems. Journal of Business Research, 1(4), 83-99.

Gerstein, M., \& Reisman, H. (1982). Creating competitive advantage with computer technology. Journal of Business Strategy, 3(1), 53-60. http://dx.doi.org/10.1108/eb038956

Graven, J. R. (2002). On the implications of the internet for insurance markets and institutions. Risk Management and Insurance Review, 5(2), 105-116. http://dx.doi.org/10.1111/1098-1616.00014

Gronroos, C. (1990). Relationship approach to marketing in service contexts: The marketing and organizational behavior interface. Journal of Business Research, 20(1), 3-11. http://dx.doi.org/10.1016/0148-2963(90)90037-E

Gummesson, E. (2008). Customer centricity: Reality of a wild goose chase? European Journal Review, 20(4), 315-330. http://dx.doi.org/10.1108/09555340810886594

Harris, S. E., \& Katz, J. L. (1988). Profitability and information technology capital intensity in the insurance industry. Proceedings of the Twenty-first Hawaii International Conference on System Sciences, 5(January). 124-130.

Henderson, J. C., \& Venkatraman, N. (1993). Strategic alignment: Leveraging information technology for transforming organizations. IBM Systems Journal, 32(1), 4-16. http://dx.doi.org/10.1147/sj.382.0472

Heskett, J. J., Sasser, W. E., \& Schlesinger, L. A. (1997). The service profit chain. New York: The Free Press.

Hyvonen, J. (2007). Strategy, performance measurement techniques and information technology of the firm and their links to organizational performance. Management Accounting Research, 18, 343-366. http://dx.doi.org/10.1016/j.mar.2007.02.001

Ives, B., \& Learmonth, G. P. (1984). The information system as a competitive weapon. Communications of the ACM, 27(12), 1193-1201. http://dx.doi.org/10.1145/2135.2137

Jeffers, P. I. (2003). Information technology and process performance: An empirical investigation of the complementarities between IT and Non-IT resources (unpublished doctoral dissertation). Graduate School 
of the Ohio State University, Ohio, USA.

Karimi, J., Somers, T. M, \& Gupta, Y. P. (2001). Impact of information technology management practices on customer service. Journal of Management Information System, 17(4), 125-158.

Keen, P. G. W. (1981). Information systems and organizational change. Communications of the ACM, 24(1). http://dx.doi.org/10.1145/358527.358543

Leavitt, H. J. (1965). Applied organizational change in industry. Handbook of organizations. January-March. Chicago: Rand-McNally.

Li, M., \& Ye, L. (1999). Information technology and firm performance: Linking with environmental, strategic and managerial context. Information Management, $35, \quad$ 43-51. http://dx.doi.org/10.1016/S0378-7206(98)00075-5

Lohman, C., Fortuin, L., \& Wonters, M. (2004). Designing a performance measurement system: A case study. European Journal of Operational Research, 156, 267-286. http://dx.doi.org/10.1016/S0377-2217(02)00918-9

Madueme, I. S. (2009). Evaluation of the impact of information communication technology on banking efficiency using the transcendental logarithmic production function and camel rating. International Journal of Engineering Science Technology, 2(1), 1-6.

Matassa, C., Neirotti, P., \& Paolucci, E. (2003). Information technology, organizational change and productivity growth: An empirical analysis of the Italian insurance industry. Retrieved from http://www.is2.ise.ac.uk/asp

McGrath, R. G., Macmillian, I. C., \& Venkatraman, S. (1995). Defining and Developing Competence: A Strategic Process Paradigm. Strategic Management Journal, 16(4), 251-275. http://dx.doi.org/10.1002/smj.4250160402

Microsoft Dynamics Report. (2009, June). Insurers boost productivity, improve service and better manage data with CRM. Retrieved from http://www.crm.dynamics.com

Morgan, R. M., \& Hunt, S. D. (1994). The commitment-Trust theory of relationship marketing. Journal of Marketing, 58(3), 20-38. http://dx.doi.org/10.2307/1252308

Murphy, T. (2000). Web rules: How the internet is changing the way consumers make choices. Chicago: Dearborn.

Ndubisi, N. O. (2007). Relationship marketing and customer loyalty. Marketing Intelligence Planning, 25(1), 98-106. http://dx.doi.org/10.1108/02634500710722425

Ndubisi, N. O., \& Wah, C. K. (2005). Factorial and discriminant analysis of the underpinnings of relationship marketing and customer satisfaction. International Journal of Bank Marketing, 23(7), 542-557. http://dx.doi.org/10.1108/02652320510629908

Nigeria Insurance Digest. (2011). Published by the Nigerian Insurers Association.

Oghojafor, B. E. A., Aduloju, S. A., \& Olowokudejo, F. F. (2011). Information technology and customer relationship management (CRM) in some selected insurance firms in Nigeria. Journal of Economics and International Finance, 3(7), 452-461.

Oyedijo, A. (2012). Strategic agility and competitive performance in the Nigerian telecommunication industry: an empirical investigation. Business and Management Review, 1(12), 39-50.

Paramasivan, T. (2008). Business strategic planning and information technology in insurance sector (4th ed.). New Delhi: Repro India Ltd.

Parsons, G. L. (1983a). Fitting information system technology to the corporate needs: The linkage strategy. Harvard Business School Teaching Note \#9-183-176. HBS Case services, Boston, Massachusetts, June.

Parsons, G. L. (1983b). Information technology: A new competitive weapon. Sloan Management Review, 25(1), 3-14.

Porter, M., \& Millar, V. E. (1985). How information gives you competitive advantage. Harvard Business Review, 63(4), 149-160.

Read, B. (2009). Top tips to build and keep customer loyalty with CRM. Customer Interactive Solution, 27(9), 26-28.

Robert-Lombard, M., \& Leon, P. (2012). Customer relationship management in a South African service 
environment: An exploratory study. African Journal of Marketing Management, 4(4), 152-165.

Rockart, J. F., \& Scott-Morton, M. S. (1984). Implications of changes in information technology for corporate strategy. Interfaces, 14(1), January-February, 84-95. http://dx.doi.org/10.1287/inte.14.1.84

Rust, R. T., \& Chung, T. (2006). Marketing models of service and relationships. Marketing Science, 3(2), 5-16.

Sawyer, O. O., Ebrahimi, B. P., \& Luk, V. W. M. (2003). Environment, executive information search activities, and firm performance: A comparative study of Hong Kong and Nigerian decision makers. International Journal of Cross Cultural Management, 3, 167-192.

Sweat, J., \& Hibbard, J. (1999). Customer disservice. Information Week, 21, 65-78.

Varki, S., \& Colgate, M. (2005). The role of price perceptions in an integrated model of behavior intentions. Journal of Service Research, 3(3), 232-240. http://dx.doi.org/10.1177/109467050133004

\section{Appendix}

\section{Details of Research Methords}

\begin{tabular}{|l|l|}
\hline Product & Insurance services \\
\hline Geographic location & Lagos, Nigeria \\
\hline Research design & cross sectional survey \\
\hline Survey instrument & personal questionnaire \\
\hline Type of sampling & stratified sampling \\
\hline Sample size & $\mathrm{N}=112$ \\
\hline Level of significance (confidence) & $5 \%(95 \%)$ \\
\hline Period of study & February - May, 2012 \\
\hline Procedure for data analysis & one sample T-test \\
\hline Test of validity & Construct, content \& external \\
\hline
\end{tabular}

\section{Key statements to research variables (Questionnaire)}

1) My organization attends to the needs of our customers via hi-tech facilities.

2) We provide on-line services to our customers through the use of IT network.

3) Our customers do their major transactions on-line without having physical contact with us.

4) My organization usually informs our customer of any transaction on their account via IT network.

5) My organization has detailed database of our customers using a blend of IT facilities.

6) All departments in my organization are familiar with the use of IT.

7) Our organization is highly computerized and as such do not restrict interaction with customers via this medium.

8) The use of IT facilities has not helped my organization to respond to customers' complaint timely.

9) IT has not improved service delivery in my organization.

10) Investment in IT has continually improved the performance of my organization over the years.

11) Quality service delivery has enhanced performance level in my organization.

12) My organization provides quality service delivery to our customers in order to improve on our performance all the time.

13) Most staff in my organization are IT oriented.

14) My organization provides IT training to all staff from time to time.

15) Many staff have disengaged due to the lack of IT integration in our service delivery.

16) Many staff lack good communication skills due to the absence of IT facilities.

17) My organization educates our customers on the need to embrace the use of IT.

18) My organization prefers service delivery without IT inclusion. 
19) IT facilities are provided in my organization.

20) Providing prompt claims payment and flexible policy plans has not affected my organization's performance.

\section{About the Authors}

IDRIS, A.A. (Ph.D) is a Lecturer in the Department of Business Administration and Management Technology, Lagos State University, Lagos, Nigeria. He holds a doctoral degree in Business Administration (Marketing), M.Sc Business Admin (Marketing), ACA, ACIS (London) and Diploma in Marketing (CIM, Berkshire). He has had over 20 years cognate hands-on experience at management level in the industry. His areas of teaching and research are selling and sales management, service marketing, strategic marketing management and entrepreneurship. He has published several scholarly articles in referred local and international journals.

OLUMOKO, T.A. (Ph.D) holds a Bachelor's degree in Economics from Lagos State University, Nigeria; M.Sc in General Management from the University of Lagos, Akoka, Lagos, Nigeria, and Ph.D in Business Administration (Marketing) from the Nasarawa State University, Nasarawa, Nigeria. He is associated with scholarly publications in books \& journals both locally and internationally. He is a lecturer in the Department of Business Administration and Management Technology (Marketing Unit), Lagos State University, Lagos, Nigeria.

AJEMUNIGBOHUN, S.S (Mr.) graduated with a Bachelor's degree in Insurance from the respected and excellent Lagos State University (LASU), Nigeria, and holds a Master's degree in Business Administration (Marketing option) from the University of Lagos, Akoka, Nigeria. He is currently on an M.Sc Risk Management and Insurance degree programme in the Department of Actuarial Science and Insurance, University of Lagos, Nigeria. He is Lecturer in the Department of Insurance, Lagos State University, Nigeria. He is involved in teaching and policy research and evaluation in the areas of Insurance marketing, Insurance management, and Insurance and Reinsurance research. His articles which covered diverse areas have appeared in both local and international journals. He belongs to several prestigious professional bodies (such as Nigerian Institute of Management, Institute of Strategic Management of Nigeria and Chartered Insurance Institute of Nigeria).

\section{Copyrights}

Copyright for this article is retained by the author(s), with first publication rights granted to the journal.

This is an open-access article distributed under the terms and conditions of the Creative Commons Attribution license (http://creativecommons.org/licenses/by/3.0/). 